\title{
Mager (Lazy-Ass) as New Culture in the Society 5.0 Era (Semiotic Analysis by Charles Pierce in the Grab Food Ad "Laper Di Kantor” Version)
}

\author{
Ari Susanti \\ Departement of Communication Studies \\ Universitas Muhammadiyah Jember \\ Jember, Indonesia \\ ari.susanti@unmuhjember.ac.id
}

\begin{abstract}
The article discusses the development of information technology and telecommunications fast-moving. This technological acceleration has an impact on world civilization which has entered the era of the society 5.0. The creation of an online application service makes it easy for humans to run all their activities. Various kinds of conveniences offered by online applications increasingly spoil the community with a lifestyle of mager (lazy to move). This picture of this phenomenon is seen in the Grab Food Advertisement "Laper Di Kantor" version. The research method used in this article is descriptive qualitative with Charles Pierce's semiotic approach. The results of this study is thet technology was created by considering aspects of mutualism. But in the reality it is not as significant as expected. One of them is the Grab application with Grab Food services creating a mager or lazy culture.
\end{abstract}

\section{Keywords - Society 5.0, Mager, and Semiotic Analysis}

\section{INTRODUCTION}

Grab is a company engaged in the field of transportation online. This start-up company established in Malaysia in 2012, at the first Grab is engaged in GrabTaxi service. over last 3 years, Grab has spread across the countries of southeast Asia. This rapid development is evident that the industrial era of 4.0 has been well received by Southeast Asian communities. Society can adapt rapidly to technology, open up to adoption of innovation and ease of access to information

The technological revolution through the Grab app impacts cultural change in society. One of Grab services that have an impact in the society is GrabFood. GrabFood seeks to provide convenience to the community to buy food and beverages through the application. With your finger, we can order what kind of food that you want. Without getting out of the chair, the order came in a short (relatively) time. It can save time. Generally, the time required for lunch break is 1 hour with details of travel time to the location of stalls or restaurant, time to cook food orders, time to eat food, and time to go back to the office/home. It is very sufficient to do all these activities with notes not being jammed in the trip and not queing when ordering food. GrabFood Service the users by providing an inter-service facility in front of consumers. Thus, consumers can utilize time for other more productive activities.
The idea of GrabFood's on-site service is contained in the GrabFood advertisement "Laper di Kantor" which can be viewed at https://www.youtube.com/watch? $\mathrm{v}=76 \mathrm{nmrZoJz10}$ In the 15 -second ad, it tells about the working woman who busy works to almost miss her lunch break, the rest of lunch break is less than 30 minutes but the other co-workers still go down through the elevator. Then she took an initiative to order lunch using GrabFood app. As a result, lunch time is faster than shopping by herself.

Technology is here to facilitate human activities as described in GrabFood commercials. Openness and ease of getting information is the facility offered by technology. In development, GrabFood App maximally benefited. For example, faster time for consideration. GrabFood partner are stalls or restaurant will prioritize orders through GrabFood. Judging from the mileage cheaper if the message GrabFood, where fuel and parking is the cost of postage.

GrabFood's facilities make it easier for its customers. On the other hand, the facility has an impact on society. Only by ordering a button through our smartphone, all orders are delivered to the doorstep. No need for overheating or rain. No need to queue or to be crowded. No need to leave a job or leave other fun activities. Hanging out at the restaurant or stall for longer, make consumers add orders that means increase spending increases. The cost-effective solution is to eat at home, in the office or elsewhere according to the consumer's condition.

People are increasingly lazy moving for food shopping with various kinds of reasons above. Without realizing it, lazy Movement (Mager) became a new culture as the impact of the application of the Industrial Era 4.0. How is the world community especially in Indonesia in facing the society 5.0 era. This study uses a semiotic analysis technique where semiotics is a tool that is able to reveal the hidden meaning in internet marketing. [1] As Gilbert Cohen-Séat said, we live in an icono-sphere world. We are surrounded by a number of different sign traits and different affiliations to the sign system. The same applies to ads that work with a sign and sign system quite significantly, using it mainly for commercial purposes.[2] 


\section{LITERATURE REVIEW}

\section{A. Society 5.0}

The 5.0 community concept was first introduced by Japanese Prime Minister Shinzo Abe aims to make a balance between technological advances and social social issues faced with the development of such technologies in an integrated and holistic. Society 5.0 is a concept where society is human-centered and technology-based.

In the era of society 4.0 with the culture developed is the 4.0 industry, people know and learn about new technology. On the one hand, the 4.0 community is enthusiastic in welcoming revolution industry 4.0. For people who tech savvy are always curious even challenged to make the technology more sophisticated. The public accesses cloud services (databases) in cyberspace through the internet for the purpose of searching, retrieving, and analyzing information or data.

But on the other hand, the adoption of innovation has varied. The more sophisticated technology, the more expensive production costs incurred. There is a gap in terms of adaptability to the latest technology, and the missed adopted due to financial and infrastructure factors. Therefore, the 4.0 industrial revolution is potentially degrades human roles dominated by technology.

Community 5.0 is the 5th Generation Science and technology plan after 4 previous generations brought the concept of hunting Society (Society 1.0), Agrarian Society (Society 2.0), Industrial society (Society 3.0) and the Information Society (Society 4.0). "Through the 5.0 community, artificial intelligence will transform the big data collected through the Internet in all areas of life (the Internet of Things) into a new wisdom, which will be dedicated to improving human abilities Opportunities for Humanity. Hopefully this transformation will help man to live a more meaningful life [3]

Artificial intelligence dominates all aspects of life. The fundamental principle of the 5.0 community is how people can optimize the artificial intelligence more productively and find solutions to problems faced, not problematic with technology. In the developed community, the presence of the 5.0 community is very helpful country economy. This is due to the slow population growth rate, resulting in a shortage of productive workforce, resulting in slow economic growth. The role of artificial intelligence will help countries with a less productive workforce.

\section{B. Mager}

The term Mager is an acronym for "Males of motion" or is lazy to move from a certain position. The term is popular among young children. The word mager has meaning as a form of rejection of a person's invitation to do an activity. The reason for this rejection is because some things are too comfortable with activities that do not want to be interrupted by other activities. For example, it's fun to play games with a meal. Not interested in other people's invitations. Not eager to do other activities when forced to do something that bothered because accustomed to doing something simple and does not require much effort. Tired or lethargic and other health reasons increasingly mager do other activities.

\section{Semiotic Analysis of Charles Sander Pierce}

The semiotic analysis that Pierce initiated has three fundamental things that are focused on his research called the Triangle meaning. The Triangle meaning is the sign, object and interpretant where the three elements are interconnected. Here is the explanation of the three elements:

- Representament or sign is a form of receipt can be word.

- Interpretant is a sign which can be interpreted or interpreted from the object referenced by the mark.

- Object is something that is referenced by the mark.

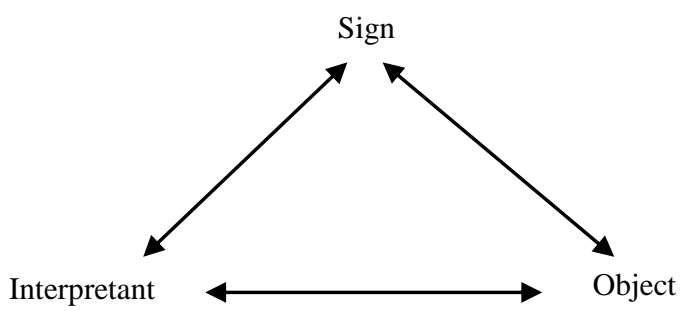

Fig. 1. Source : [4]

According to Pierce, the sign is divided into 3 categories namely icons, index and symbols. See the explanation in the following table:

TABLE I. DIFERENCE BETWEEN ICON, INDEX AND SYMBOL

\begin{tabular}{|l|l|l|l|}
\hline \multicolumn{1}{|c|}{ Sign } & \multicolumn{1}{c|}{ Icon } & \multicolumn{1}{c|}{ Index } & \multicolumn{1}{c|}{ Symbol } \\
\hline $\begin{array}{l}\text { Characterized } \\
\text { by: }\end{array}$ & $\begin{array}{l}\text { Equations } \\
\text { (similarities) }\end{array}$ & Causal relationship & Convention \\
\hline Example: & $\begin{array}{l}\text { Pictures and } \\
\text { statues of big } \\
\text { figure Reagen } \\
\text { Photos }\end{array}$ & $\begin{array}{l}\text { Smoke/Fire } \\
\text { Symptoms/Diseases }\end{array}$ & Cue words \\
\hline Process: & Viewable & Predictable & $\begin{array}{l}\text { Must be } \\
\text { Learned }\end{array}$ \\
\hline
\end{tabular}

a. Source : [5]

The signs mentioned above can be described as a reality relationship with the following basic types [6]

- Icon: something that performs the function as a marker similar to the object's shape (seen in the picture, painting even the film),

- Index: Something that carries out a function as a marker that suggests its map,

- Symbol: something that carries out functions as a marker by convention conventions has been commonly used in society.

\section{RESEARCH METHOD}

The type of research in this article is a qualitative content analysis using the semiotic analysis of Charles Sander Pierce. Researchers analyze something that does not appear or content of implied communication in GrabFood commercials. Researchers strive to analyse thoroughly and find as many data as possible about the phenomenon of Mager from various points of view. The focus of this research is the GrabFood advertisement of "Laper di 
Kantor"version where one of the impacts of the service is the creation of a new culture of Mager culture.

\section{RESUlt AND DisCUSSION}

\section{A. Semiotic Analysis of Charles Sander Pierce}

GrabFood advertisement of Laper version in the office has a 15-second viewing duration consisting of 4 scenes telling the story of a busy work in the office to forget the rest of the time. Without noticeably, rest time remaining 30 minutes. When you want to go looking for lunch, it turns out that in front of the elevator still many colleagues who queued to wait for the lift. Then the masterpiece has an idea to use GrabFood service by ordering food from restaurants nearby. The results are easier and time-saving.

This article is a further review of Grab Food ad Laper version in office where this video writer download from https://www.youtube.com/watch?v=76nmrZoJz10 . There are three main things to explain the meaning of the ad based on the triangle meaning of Charles Sander Pierce:

\section{2) Sign}

The sign referred to in this article is GrabFood advertisement. As a sign in general GrabFood ads it has a distinguishing identifier with other GrabFood advertisements. Therefore, GrabFood's advertisement referred to in this article is "Laper di Kantor" version. It is evident when writing GrabFood ads "Laper di Kantor" version in the search engines will appear in the first row. This is what makes GrabFood ads "Laper di Kantor"version as a sign.

\section{3) Object}

Object in the video ad GrabFood version of "Laper di Kantor" with a duration of 15 seconds consisting of 4 scenes is the ad produced by TVCoMM ads and published on July 11,2019 . This ad has been watched for 1,869 times and gets 6 likes and 2 dislike. These ads can be viewed on the page: https://www.youtube.com/watch? $v=76 \mathrm{nmrZoJz} 10$

\section{4) Interpretant}

The interpretant is the interpreted meaning GrabFood ads have a message that GrabFood delivers a message delivery service that makes it easy for its customers to be delivered even directly to their customers. The stated meaning in the advertisement is speed and accuracy in the booking without compromising the excellent service.

To facilitate the understanding of meaning in GrabFood ads in "Laper di Kantor" version, the following describes the meanings contained in each scene:

TABLE II. SCENE 1 AN OFFICER IS BUSY WORKING

\begin{tabular}{|l|l|l|}
\hline Visual & \multicolumn{1}{|c|}{ Verbal } \\
\hline "Makan . dulu \\
sempet nih..."
\end{tabular}

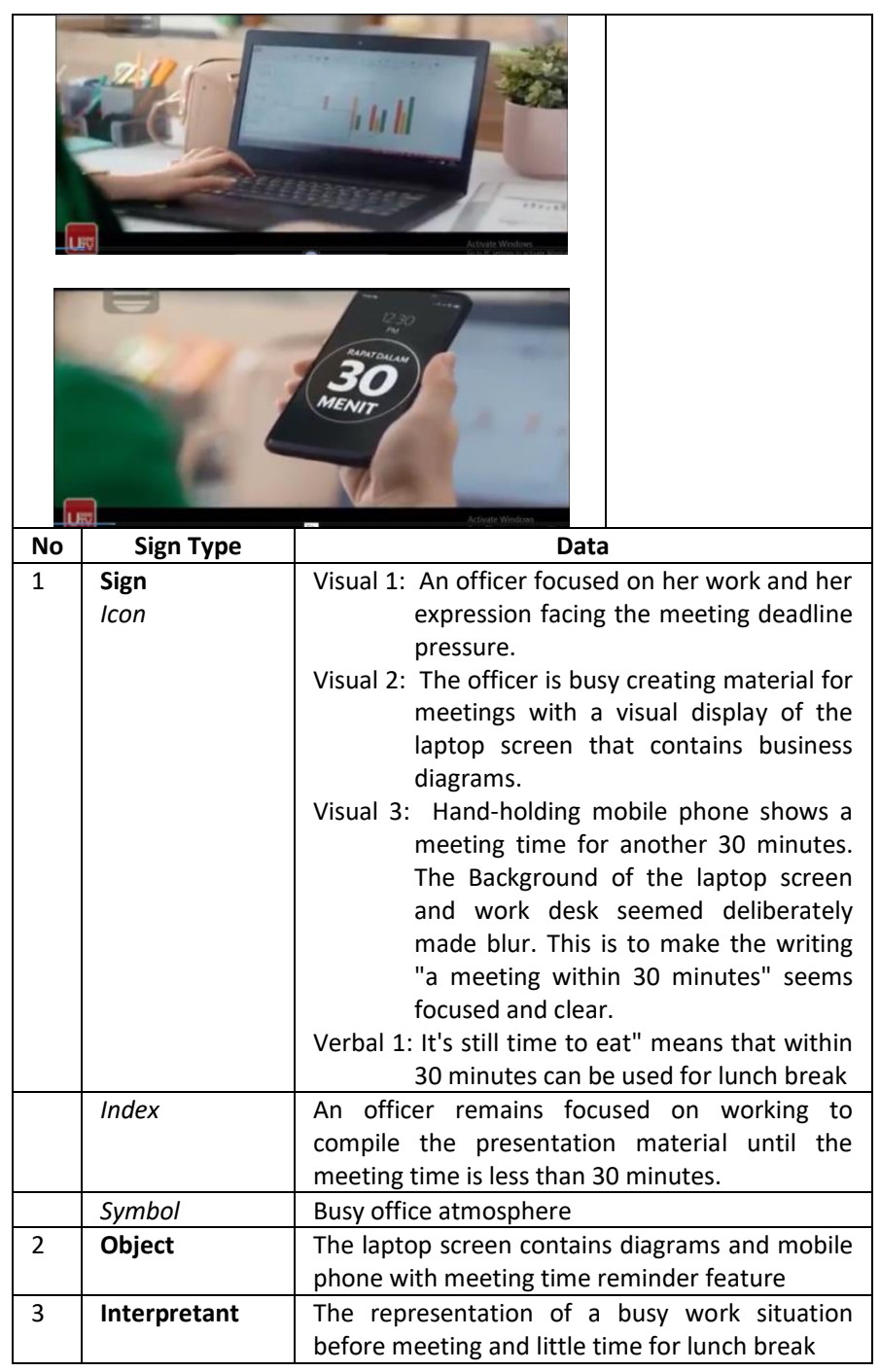

TABLE III. SCENE 2 QUEUED IN THE ELEVATOR

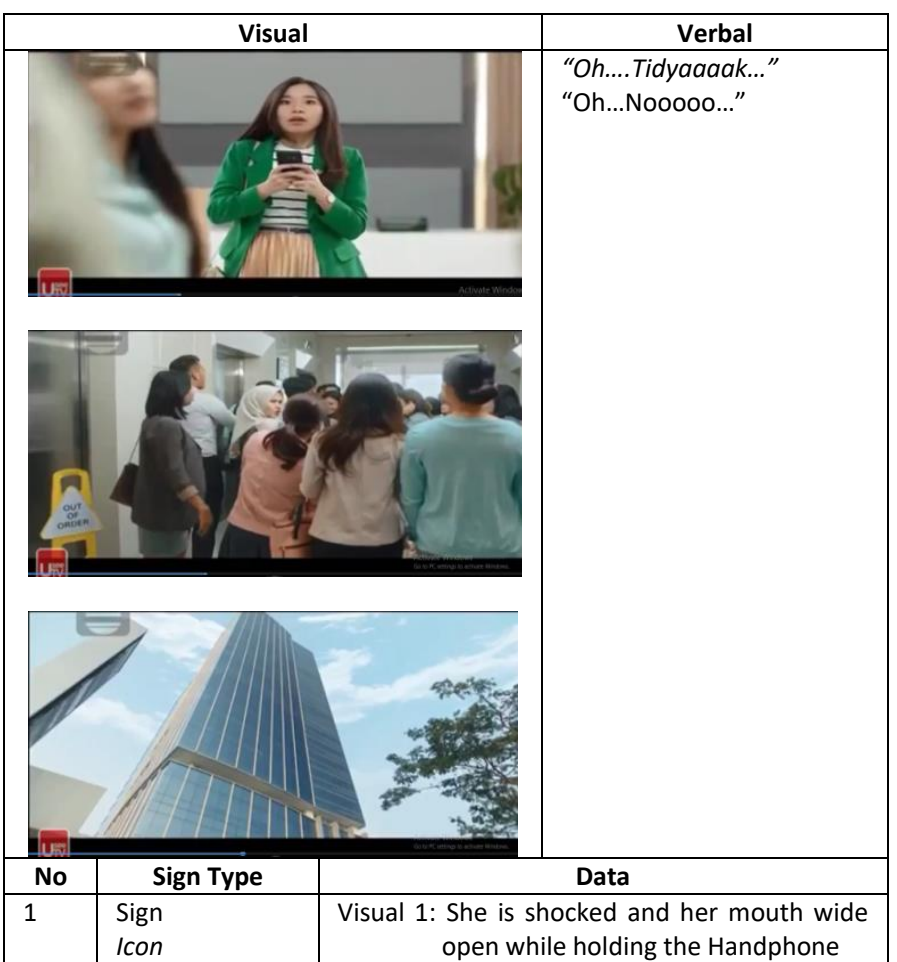




\begin{tabular}{|l|l|l|}
\hline & & $\begin{array}{r}\text { Visual 2: The situation in front of the elevator } \\
\text { is very crowded waiting for a turn } \\
\text { while having fun with chatting. } \\
\text { Visual 3: The picture of the workplace building } \\
\text { is a high office building. } \\
\text { Verbal 1: "Oh...Nooo..." With a surprised voice } \\
\text { accompanied by screaming is an } \\
\text { expression of frustration where the } \\
\text { worker imagined it could not have } \\
\text { lunch with a short break time. }\end{array}$ \\
\hline & Index & $\begin{array}{l}\text { She was shocked by the number of queues in } \\
\text { front of the elevator while the building had } \\
\text { more than 10 floors so it could not be allow } \\
\text { for a lunch break 30 minutes left }\end{array}$ \\
\hline 2 & Object & $\begin{array}{l}\text { The situation in front of the bustling elevators } \\
\text { and high office buildings }\end{array}$ \\
\hline 3 & Interpretant & $\begin{array}{l}\text { Shocked expressions, the situation in front of } \\
\text { bustling elevators and skyscrapers }\end{array}$ \\
\hline $\begin{array}{l}\text { The representation of lunch break is a war } \\
\text { where the elevator queue becomes one of the } \\
\text { indicators. }\end{array}$ \\
\hline
\end{tabular}

TABLE IV. SCENE 3 ORDER GRABFoOd Please

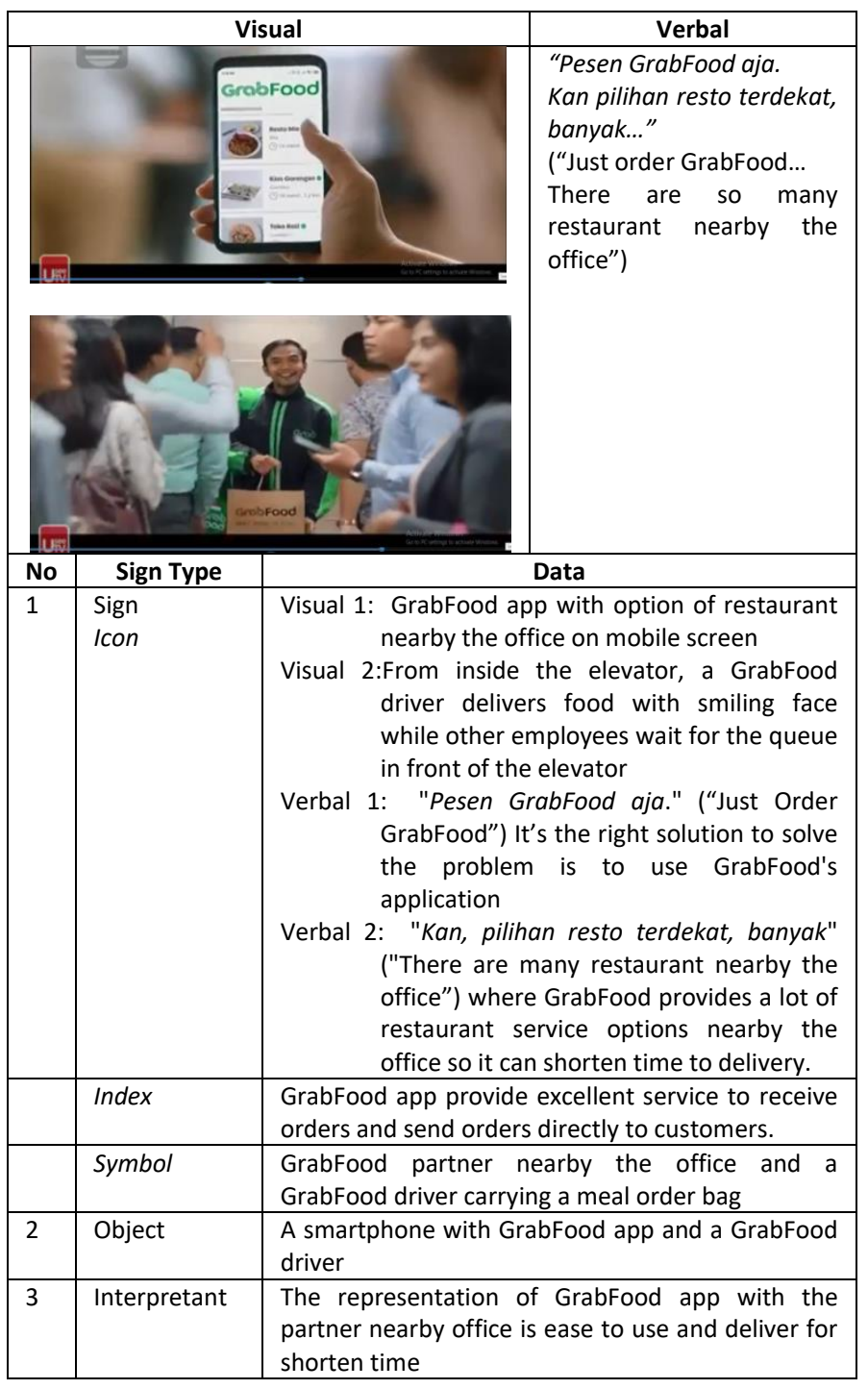

TABLE V. Scene 4 GrabFood MENu Nearby OfFice

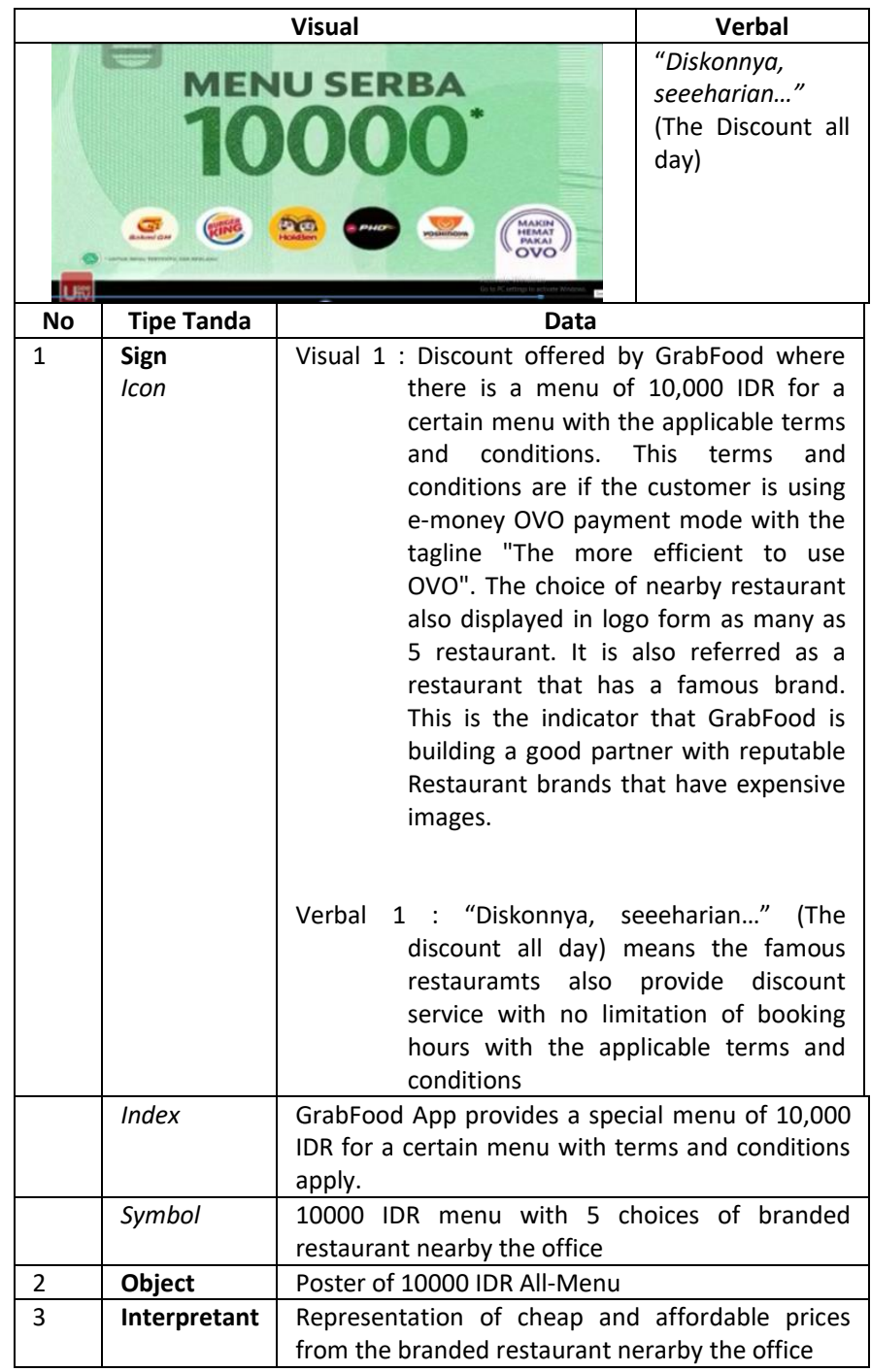

\section{B. Mager Representation on GrabFood ads}

GrabFood's advertisement for smart solutions in the busy office day is an interesting phenomenon to be researched. GrabFood application is made to facilitate human activity in a simple matter that is sufficient willingness of lunch menu in the office. GrabFood app is made to facilitate human activity in terms of lunch menu readiness in the office. This service can also receive orders in large quantities for example for the consumption of the meeting with the easy payment mode by using e-money via OVO, bank transfer (both mobile banking and internet banking) and cash on delivery mode. So that it can save customer time and delivery compared to conventional ordering. Conventional ordering takes a lot of time to complete all orders. Now all can be done in the hand without getting out from the work desk, ready to transfer and directly handed to the customer.

The society 4.0 is dominated by information technology that seeks to adopt the maximum technology of absorbing and implementing. The difference between new people learn to empowering technology and the community who empowered by technology is very thin. The meaning of empowering technology is the society empowering technology to make it easier for every activity to work, school and household interests. For example, search for job 
and school work information by utilizing the Internet. While the technology deceived is the society becomes unable to be independent because the technology dominates every activity. For example if we count something is not confident if not using a calculator.

There is a dichotomy in the industrial era 4.0. First, to facilitate all human activity in everyday life. Second, to make human beings to the level unable to be independent as human being. The convenience of this technology will make a new social problem in the future. GrabFood's advertisements discussed in this article provide convenience in ordering food over the internet. As a public application, GrabFood not only caters to employees in the office but also serves all walks of life including housewives, students, and even the business interests (Broker/Realtor) of food. By pressing the buttons in GrabFood app, in a short time the food is already available at the table. These facilities are reviewed in the semiotics analysis of Pierce above.

This article discusses more about the negative impact of GrabFood ads where humans experience a degradation of activity, which is mager (males of motion). The society is spoiled by the technological facilities that can be accessed in the hand. If in the society Era 4.0 this course, the society experienced a decline in human role then how the Community condition 5.0. Here are the predictions of the community condition 5.0, among others:

\section{1) Cooking in the family kitchen will be disappear.}

Cooking requires a process. its means time to cooking relatively long (depending on the type of food) and the energy spent sometimes does not worthed with the outcome. So cooking is troublesome, spending a lot of time, and wasting energy.

\section{2) Home-cooked menu becomes rare}

Family members are not able to cook certain menus especially those that require accuracy and persistence in their workmanship. Even they does not know about spices, types of vegetables, and a type of healthy protein to consume.

\section{3) Cooking is extravagant.}

For urban people, family members lose time together because of their busy activities. So that the house has already lunch or dinner before coming home. Finally, the food provided in the house becomes redundant. In addition, preparing meals for 2 people or 5 people spend not much different funds, for example the amount of gas/fuel, cooking oil and cooking time is almost the same. Only the quantity is different.

4) The society becomes less socialization and street blindness because it is rarely out of comfort zone.

Basically, have a dinner or lunch at home is cheaper than at the restaurant. In the restaurant, the possibility of adding a menu or just satisfaction our curiousity. The beverage price is also almost the same as the food menu. Drinking at home is more efficient than drinking at the restaurant. GrabFood app gives you an intercompany messaging service in front of the house without needing to go somewhere.

The word mager contains negative meanings. Lazy to do something contrary to the condition of society that is expected in the society 5.0 era where people are trying to enjoy a more quality life, compete in pursuit of success and other things more productive. Technological advances are proactive, not otherwise neglected and dependent on technology so that the quality of life of the society 5.0 who are more humanized will manifest.

\section{CONCLUSION}

Based on the results of the above analysis can be concluded that Mager (males gerak) is a new culture created from the sophistication of information technology. In this article discusses the application GrabFood makes the society increasingly mager. Although the technology was created by considering the aspect of mutualism but society is not ready to face the society 5.0 era. The application is expected GrabFood in the society 5.0 will help humans productively and not otherwise where the culture of working in the kitchen begins to disappear, cooking home-cooked menu becomes rare, the paradigm that cooking is wasteful and society less for socialization and road blindness because it is rare out of comfort zones.

\section{REFERENCES}

[1] D. Tsotra, M. Janson, and D. Cecez-Kecmanovic, "Marketing on the Internet: A Semiotic Analysis," in Proceedings of the Tenth Americas Conference on Information Systems, 2004, no. August, pp. 42104220, [Online]. Available: http://aisel.aisnet.org/amcis2004/526.

[2] M. Solík, "Semiotic approach to analysis of advertising," Eur. J. Sci. Theol., vol. 10, pp. 207-217, 2014.

[3] D. Mayasari, "Mengenal Society 5.0, Transformasi Kehidupan yang Dikembangkan Jepang | TIMES Indonesia," 2019. https://www.timesindonesia.co.id/read/news/197889/mengenalsociety-50-transformasi-kehidupan-yang-dikembangkan-jepang (accessed Mar. 01, 2020).

[4] J. Fiske, Cultural and communication studies: Sebuah pengantar paling komprehensif. Yogyakarta: Jalasutra, 1990.

[5] S. Alex, Semiotika Komunikasi. Bandung: Remaja Rosdakarya, 2003.

[6] S. Alex, Analisis Teks Media: Suatu Pengantar untuk Analisis Wacana, Analisis Semiotik, dan Analisis Framing. Bandung: PT Remaja Rosdakarya, 2009. 